\title{
Dissipation Studies of Thiamethoxam on Capsicum under Field and Poly House Conditions
}

\author{
V. L. Pathipati ${ }^{*}$, T. V. K. Singh ${ }^{2}$, S. B. Vemuri ${ }^{3}$, R. V. S. K. Reddy ${ }^{4}$, \\ N. B. Bharathi ${ }^{5}$, N. R. Reddy $^{6}$ and Aruna $^{7}$
}

${ }^{1}$ (Entomology) and Principal, HPT, Dr YSR Horticultural University, Andhra Pradesh, India

2 (ICAR), PJTSAU, Rajendranagar, Hyderabad, Telangana, India

${ }^{3}$ AINP on Pesticide Residues, PJTSAU, Rajendranagar, Hyderabad, Telangana, India

${ }^{4}$ Dr YSR Horticultural University, Andhra Pradesh, India

${ }^{5}$ Department of Plant Pathology, PJTSAU, Rajendranagar, Hyderabad, Telangana, India

${ }^{6}$ Department of Entomology, PJTSAU, Rajendranagar, Hyderabad, Telangana, India

${ }^{7}$ AINP on Pesticide Residues, PJTSAU, Rajendranagar, Hyderabad, Telangana, India

*Corresponding author

\section{A B S T R A C T}

\begin{tabular}{|l|}
\hline Ke y w or d s \\
$\begin{array}{l}\text { Capsicum, thiamethoxam, } \\
\text { dissipation, field, poly } \\
\text { house conditions }\end{array}$ \\
\hline Article Info \\
\hline $\begin{array}{l}\text { Accepted: } \\
17 \text { May } 2018 \\
\text { Available Online: } \\
\text { 10 June } 2018\end{array}$ \\
\hline \hline
\end{tabular}

Thiamethoxam $25 \% \mathrm{WG}$ is a second neonicotinoid with highly systemic and broad spectrum insecticide used against sucking pests of vegetables in India. Thiamethoxam residues were quantified through regular sampling till the residues are below determination level (BDL) of $0.05 \mathrm{mg} \mathrm{kg}^{-1}$ following the validated QuEChERS method. The qualitative and quantitative analysis of thiamethoxam was performed on LC- MS/MS(PDA). Initial deposits of $1.62 \mathrm{mg} \mathrm{kg}^{-1}$ were detected in capsicum samples collected from open filed, which dissipated to BDL in 7.0 days while in poly house, initial deposits of $2.77 \mathrm{mg} \mathrm{kg}^{-1}$ were dissipated to BDL in 15.0 days. The waiting period for safe harvest was worked out to be 10.0 and 15.0 days when thiamethoxam25\% WG@ $50 \mathrm{ml}$ a.iha ${ }^{-1}$ sprayed thrice in open and poly house conditions, respectively. Dissipation is slow in poly house compared to open fields due to various factors. In both situations initial deposits are lower than the MRL (10 $\mathrm{mg} \mathrm{kg}^{-1}$ ) of Codex Alimentarius Commission hence a pre-harvest interval of 7.0 and 15.0 day is recommended.

\section{Introduction}

Capsicum (Capsicum annuum L. var. grossum Sendt.) is also called as bell pepper or sweet pepper and is one of the most popular and highly remunerative annual herbaceous vegetable crop. Capsicum is cultivated in most parts of the world, especially in temperate regions of Central and South America and
European countries, tropical and subtropical regions of Asian continent mainly in India and China. Various biotic (pest and diseases), abiotic (rainfall, temperature, relative humidity and light intensity) and phonological factors (flower and fruit drop) limits the yield and fruit quality under open field conditions (Hebbar et al., 2011). Among the biotic factors, insect pests reduces the quality of 
produce and even a small blemish on the fruit will drastically reduce its market value. Butani (1976) reported over 20 insect species on chillies (Capsicum spp.) from India of which thrips, Scirtothrips dorsalis Hood, mite, Polyphagotarson emuslatus Banks are among the most damaging pests (Ananthakrishnan, 1971, Krishna Kumar, 1995 and Moorthy et al., 2013) under field conditions. In addition to these pests, aphid, Myzuspersicae (Sulz.), whitefly, Bemisiatabaci (Gennadius), leaf miner, Liriomyzatrifolii (Burgess), gall midge, Asphondyliacapsici Barens and nematodes, Meloidogyne incognita Chitwoodare serious problems on capsicum under protected condition (Barwal, 2004 and Kaur et al., 2010). Reddy and Kumar (2006) estimated crop loss of 40 to 60 tons per ha of capsicum when the crop was not subjected to insecticidal control.

Among the insecticides thiamethoxam $25 \%$ WGis highly systemic and broad spectrum insecticide used against sucking pests of capsicum (Kodandaram et al., 2010). Since capsicum is consumed afresh, they may carry residues, the analysis of pesticide residues in capsicum is therefore essential to avoid the health hazards to the consumers by prescribing the waiting periods. To compare the residues in open and poly house conditions, the present study was conducted.

\section{Materials and Methods}

Certified Reference Materials (CRMs) of thiamethoxam, obtainedfrom Dr. Erhenstorfer, Germany were used to prepare primary standards. Intermediary and working standards were prepared using acetone and hexane as solvents (1: 9 ratio).

Working standards were prepared in the range of $0.01 \mathrm{ppm}$ to $0.5 \mathrm{ppm}$ in $10 \mathrm{ml}$ calibrated graduated volumetric flask using distilled nhexane as solvent. All the standards were stored in deep freezer maintained at $-40^{0} \mathrm{C}$. Limit of detection and linearity of thiamethoxam was done on LC-MS/MS. The LC operating parameters for thiamethoxam were detection and estimation are presented in Table 1.

Prior to pesticide application and field sample analysis, the residue analysis method was validated following the SANCO document (12495/2011). The AOAC official method 2007.01 (Pesticide Residues of Foods by Acetonitrile Extraction and Partitioning with Magnesium Sulphate) was slightly modified to suit to the facilties available at the laboratory and the same was validated for estimation of LOQ (Limit of Quantitation) in capsicum matrix. The final extract of the sample was evaporated using turbo vap and made up to 1 $\mathrm{ml}$ (equal to $1 \mathrm{~g}$ sample) using suitable solvent for LC analysis, filtered $1 \mathrm{ml}$ final extract (equal to $0.5 \mathrm{~g}$ sample) was directly injected in LC and the residues of pesticides recovered from fortified samples were calculated using the standard formula.

Samples of capsicum were collected from both the poly house and open field from individual treatments in all the replications after three sprays, in labeled polybags. Care was taken to avoid contamination by wearing hand gloves. Pest damage free and crack free capsicum fruits collected in separate polythene bags were brought to the laboratory at regular intervals i.e. $0,1,3,5,7,10,15$ and 20 days after last spray from both poly house and open field. Collected samples were analyzed for residues by the validated methods.

\section{Results and Discussion}

The dissipation dynamics of thiamethoxam were studied in open field and poly house situation, by collecting samples at $0,1,3,5,7$, 10, 15 and 20 days after three sprays of thiamethoxam@150 g ha ${ }^{-1}$ the third spray and 
results are presented in Tables 2, 3 and Fig 1. In open field situation, initial deposits of 1.62 $\mathrm{mg} \mathrm{kg} \mathrm{kg}^{-1}$ thiamethoxamat 2 hours after last spray, dissipated to $1.32,0.81$ and $0.44 \mathrm{mg} \mathrm{kg}^{-}$ ${ }^{1}$ by 1,3 and 5 days after last spray, respectively. The residues reached BDL at $7^{\text {th }}$ day after spray. The dissipation pattern showed decline of residues and residues dissipated by $18.50,50.00,72.83$ and 100.00 at $1,3,5$ and 7 days, respectively. The regression equation is $\mathrm{Y}=3.225+(-0.113) \mathrm{X}$ with $\mathrm{R}^{2}$ of 0.994 . The half - life values and safe waiting period for harvest in open field was 1.65 and 7.00 days, respectively.

Table.1 Details of LC-MS/MS operating parameters for the analysis of thiamethoxam

\begin{tabular}{|l|}
\hline LC-MS/MS \\
\hline Detector \\
\hline Column \\
\hline Column Oven Temperature \\
\hline Retention Time (RT) \\
\hline Nebulizing gas \\
\hline Nebulizing flow gas \\
\hline Pump Mode/ flow \\
\hline Retention time, \\
\hline LC Program \\
\\
\hline Precursor ion and Quantifier \\
ion
\end{tabular}
SHIMADZU LC-MS/MS 8040

Mass Spectrophotometer

KINETEX, 100 X 3, 2 um

$40^{\circ} \mathrm{C}$

5.1

Nitrogen

2.0 lit. $\mathrm{min}^{-1}$

Gradient/ $0.4 \mathrm{ml} . \mathrm{min}^{-1}$

Thiamethoxam - 4.12 min.

A : Ammonium formate in water

B : Ammonium formate in methanol

\begin{tabular}{|l|c|c|c|}
\hline Insecticide & Time & methanol & Water \\
\hline Flubendiamide & 4.01 & 35 & 65 \\
\hline Insecticide & Precursor ion & Quantifier ion \\
\hline Flubendiamide & 293.50 & \multicolumn{2}{|c|}{211.10} \\
\hline
\end{tabular}

Table.2 Dissipation of thiamethoxam in capsicum in open field conditions

\begin{tabular}{|c|c|c|c|c|c|}
\hline \multirow[t]{2}{*}{ Days after last spray } & \multicolumn{4}{|c|}{ Residues of thiamethoxam $\left(\mathrm{mg} \mathrm{kg}^{-1}\right)$} & \multirow[t]{2}{*}{ Dissipation \% } \\
\hline & R1 & $\mathbf{R} 2$ & $\mathbf{R 3}$ & Average & \\
\hline $\mathbf{0}$ & 1.65 & 1.61 & 1.60 & 1.62 & 0.00 \\
\hline 1 & 1.30 & 1.32 & 1.33 & 1.32 & 18.50 \\
\hline 3 & 0.79 & 0.82 & 0.81 & 0.81 & 50.00 \\
\hline 5 & 0.41 & 0.46 & 0.44 & 0.44 & 72.83 \\
\hline 7 & BDL & BDL & BDL & BDL & 100.00 \\
\hline 10 & BDL & BDL & BDL & BDL & --- \\
\hline 15 & BDL & BDL & BDL & BDL & -- \\
\hline 20 & BDL & BDL & BDL & BDL & -- \\
\hline Regression equation & \multicolumn{5}{|c|}{$Y=3.225+(-0.113) X$} \\
\hline $\mathbf{R}^{2}$ & \multicolumn{5}{|l|}{0.994} \\
\hline Half-life & \multicolumn{5}{|l|}{1.65} \\
\hline
\end{tabular}


Table.3 Dissipation of thiamethoxam in capsicum in poly house conditions

\begin{tabular}{|c|c|c|c|c|c|}
\hline \multirow[t]{2}{*}{ Days after last spray } & \multicolumn{4}{|c|}{ Residues of thiamethoxam $\left(\mathrm{mg} \mathrm{kg}^{-1}\right)$} & \multirow[t]{2}{*}{ Dissipation \% } \\
\hline & R1 & $\mathbf{R} 2$ & R3 & Average & \\
\hline $\mathbf{0}$ & 2.77 & 2.79 & 2.76 & 2.77 & 0.00 \\
\hline 1 & 2.01 & 2.04 & 2.06 & 2.04 & 26.35 \\
\hline 3 & 1.75 & 1.77 & 1.72 & 1.75 & 36.82 \\
\hline 5 & 0.88 & 0.81 & 0.83 & 0.84 & 69.67 \\
\hline 7 & 0.42 & 0.40 & 0.44 & 0.42 & 84.83 \\
\hline 10 & 0.09 & 0.07 & 0.08 & 0.08 & 97.11 \\
\hline 15 & BDL & BDL & BDL & BDL & 100.00 \\
\hline 20 & BDL & BDL & BDL & BDL & -- \\
\hline Regression equation & \multicolumn{5}{|c|}{$Y=3.444+(-0.095) X$} \\
\hline $\mathbf{R}^{2}$ & \multicolumn{5}{|l|}{0.926} \\
\hline Half-life & \multicolumn{5}{|c|}{2.03 days } \\
\hline
\end{tabular}

Fig.1 Dissipation of thiamethoxam in capsicum in open field and poly house conditions

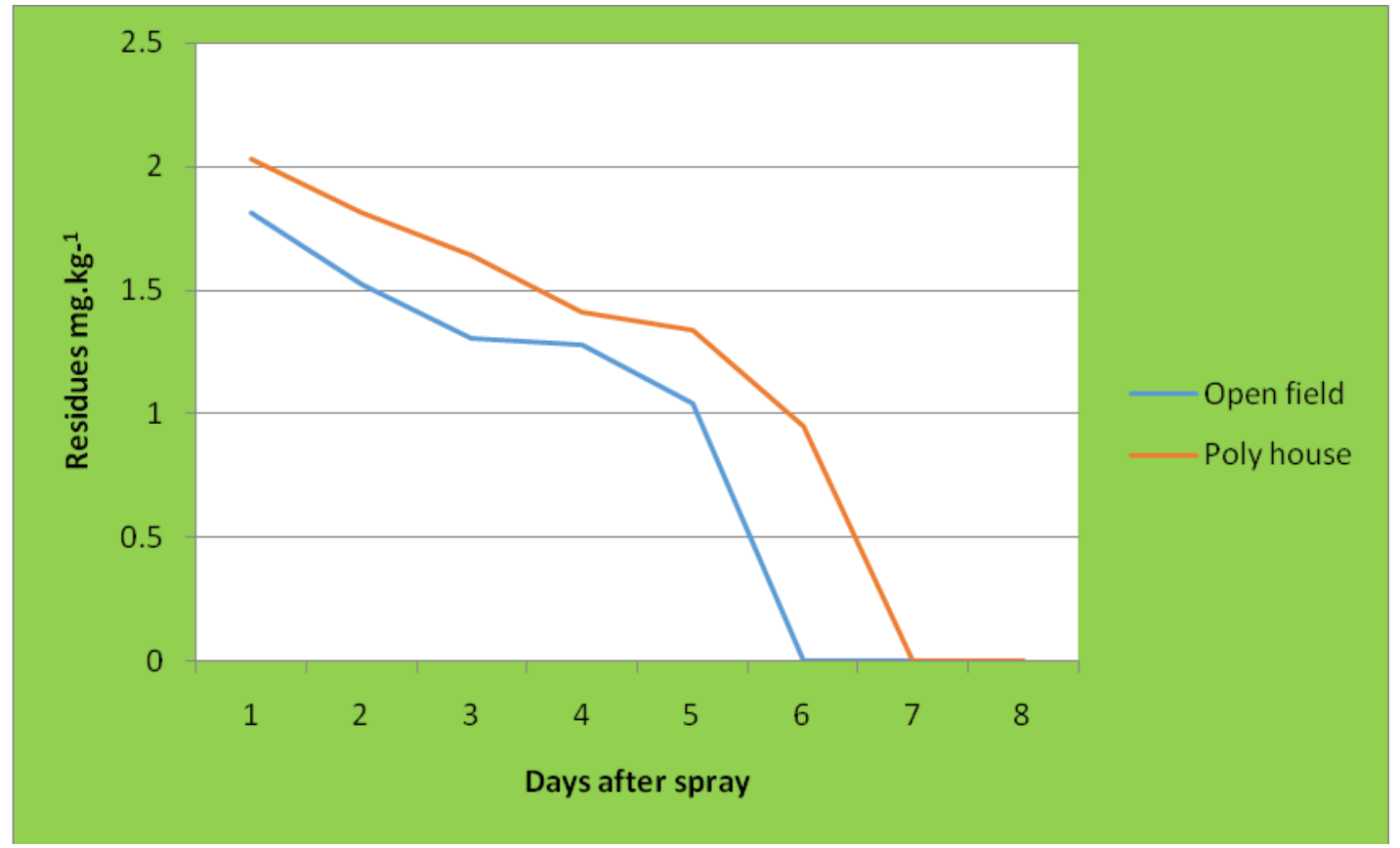

In poly house, initial deposits of $2.77 \mathrm{mg} \mathrm{kg}^{-1}$ thiamethoxam detected at 2 hours after last spray, dissipated to $2.04,1.75,0.84,0.42$ and $0.08 \mathrm{mg} \mathrm{kg}^{-1}$ by $1,35,7$ and 10 days after last spray, respectively. The residues reached BDL at $15^{\text {th }}$ day after spray. The dissipation pattern showed decrease of residues from first day to $15^{\text {rd }}$ day and the residues dissipated by $26.35,36.82,69.67,84.83,97.11$ and 100.00 per cent at $1,3,5,7,10$ and 15 days, respectively. The regression equation is $\mathrm{Y}=$ $3.444+(-0.095) \mathrm{X}$ with $\mathrm{R}^{2}$ of 0.926 . The half - life value was worked out by using linear semi-logarithmic regression analysis 
(Hoskins, 1961) and found to be 2.03 days. The safe harvest time interval after three sprays of thiamethoxam @ $150 \mathrm{~g} \mathrm{ha}^{-1}$ in poly house conditions was 15.00 days.

The literature on dissipation of thiamethoxam is scanty, the results are discussed here under. Singh and Kulshrestha (2005) recorded the initial deposits of $0.475 \mu \mathrm{g} \mathrm{g}^{-1}$ after two applications of thiamethoxam at 140 and $75 \mathrm{~g}$ $\mathrm{ha}^{-1}$ doses and 95.2 per cent dissipation was recorded on the $5^{\text {th }}$ day after last spray and were BDL by the $7^{\text {th }}$ day. The variation in the initial deposits (1.62 and $2.77 \mathrm{mg} \mathrm{kg}^{-1}$ in open and poly house conditions, respectively) halflife (2.65 and 2.03 days), waiting periods (7.00 and 15.00 days) and dissipated to BDL (7.00 and 15.00 days) of capsicum may be due to variation in dosages of application, change in matrix and climatic conditions.

Comparison of dissipation pattern of above insecticides in capsicum in open field and poly house conditions indicated that, initial deposits, half - life and waiting periods were less in open field conditions than poly house conditions (Figure 1). This data infers that the dissipation is slow in poly houses compared to open fields due to varying factors such as cool climatic conditions and less sun light penetration in poly house. The residues of flubendiamide degraded to below the maximum residue limit notified by Codex Alimentarius Commission (FAO/WHO) after 7 days in open field and 15 days in polyhouse. The results of the study indicated that flubendiamide applied to capsicum under controlled environmental conditions required longer pre-harvest interval to allow its residues to dissipate to the safe level.

\section{References}

Ananthakrishnan, T.N.1971. Thrips: Biology and control. McMillan Company of India, Delhi Press, pp: 120.
Barwal, R. N. 2004. Loss to sweet pepper, Capsicum annum Linn. Seedlings by the first generation caterpillars of cabbage cutworm, Agrotisipsilon (Hufn,). Pest Management in Horticultural Ecosystem. 5 (2): 139-141.

Butani, D. K., 1976, Pests and diseases of chilli and their control. Pesticides, 10: 38-41.

Hebbar, S.S., Balakrishan, B., Prabhakar, M., Srinivas,V., Anil Kumar, N., Ravi Kumar., Girija, G., Debi Sharma., Sudhakar, R.V., Doijode, D., Hegde, M.R and Rao, M.S. 2011 Protected Cultivation of Capsicum. IIHR Technical Bulletin: 22

Hoskins, W. M. 1961. Mathemetical treatments of loss of pesticide residues. Plant Protection Bulletin, FAO. 9: 163 168.

Kaur, S., Kaur, S., Srinivasan, R., Cheema, D.S., Tarsem Lal., Ghai, T.R and Chadha, M.L. 2010. Monitoring of major pests on cucumber, sweet pepper and tomato under net house conditions in Punjab, India. Pest Management in Horticultural Ecosystems. 16 (2): 148155.

Kodandaram, M. H., Rai, A.B andJaydeep, H., 2010. Novel insecticides for management of insect pests in vegetable crops: A review. Vegetable Science. 37 (2): 109-123.

Krishna Kumar, N.K. 1995. Yield loss in chilli and sweet pepper due to Scirtothrips dorsali Hood. Pest Management in Horticultural Ecosystems. 1 (2):61-69.

Moorthy, P. N. K., Saroja, S and Shivaramu, K. 2013. Bio-efficacy of neem products and essential oils against thrips (Scirtothrips dorsalis Hood) in capsicum. Pest Management in Horticultural Ecosystes 19(2): 191 193. 
Reddy, E. S. G and Kumar, K. N. K. 2006. Integrated management of yellow mite, Polyphagotarsonemuslatus Banks on sweet pepper grown under poly house. Journal of Horticultural Science. 1 (2): 120-123.

Singh, S.B and Kulshrestha, G. 2005. Residues of thiamethoxam and acetamiprid, two neonicotinoid insecticides in/on okra fruits (Abelmoschus asculentus L.). Bulletin of Environmental Contamination and Toxicology. 75 (5): 945-951.

\section{How to cite this article:}

Pathipati V. L., T. V. K. Singh, S. B. Vemuri, R. V. S. K. Reddy, N. B. Bharathi, N. R. Reddy and Aruna. 2018. Dissipation Studies of Thiamethoxam on Capsicum under Field and Poly House Conditions. Int.J.Curr.Microbiol.App.Sci. 7(06): 1688-1693.

doi: https://doi.org/10.20546/ijcmas.2018.706.200 